\title{
THE IMPACT OF SLOWER GROWTH AND DEINDUSTRIALIZATION UPON STATE OUTPUT VOLATILITY
}

\author{
Paul R. Blackley*
}

\begin{abstract}
This article reviews previous empirical analyses of the relation between economic growth and volatility for regional and state economies. Gross state product data are used to document the extent to which slower overall growth and deindustrialization occurred during the past three decades in the United States. Estimates are presented for two models that demonstrate that output volatility is explained by changes in growth over time rather than longer-term average rates of growth. Industry structure variables and absolute measures of economic size are also found to be significant determinants of state output volatility.
\end{abstract}

\section{INTRODUCTION}

Two often stated goals of state govemments are the achievement of a higher rate of long-term economic growth and a reduction in the short-term volatility of output and employment. An improvement in secular growth enables an expansion of employment opportunities for growing labor forces and provides for steady increases in the economic bases of state revenue systems. Avoidance of large fluctuations in output prevents the strains on existing resources that occur when either rapid increases in growth require more public services and infrastructure than they can be supplied, or steep declines create revenue shortfalls at a time when countercyclical spending programs are needed.

The importance of these goals has generated considerable research designed to identify whether there is either a mutually reinforcing or a trade-off relationship between regional economic growth and volatility. Results from this work reviewed below are mixed and appear to depend upon issues related to proper model specification and the definitions of several key variables. Recent evidence based upon more comprehensive attempts to model the determinants of regional cyclical volatility indicates that earlier theoretical work positing either a positive or negative relation between economic growth and volatility is incomplete. This has been due to both weak model assumptions and a failure to recognize an asymmetry between the effects of growth and decline upon volatility. Building upon these findings, this article extends the theoretical and empirical framework for assessing the growth-volatility relation.

\footnotetext{
*Professor of Economics, Le Moyne College. The author gratefully acknowledges the helpful comments of an anonymous reviewer.
} 
In particular, a serious shortcoming in research covering the 1960-1980s period is the implicit assumption of constant long-term regional growth rates when relating growth to the level of volatility. However, it is well known that events contributing to the national recession of 1974-75 initiated a period of structural economic adjustments with different impacts across regions. Documented below for state economies are the significant changes in total output and manufacturing output growth rates that occurred after 1973 and the substantial interstate variation in the extent of slowdowns that resulted. Thus, a model that implies that the volatility in annual output growth is related to changes in long-term economic growth is developed and estimated. A significant negative relation is found for both total output and the manufacturing sector of the economy. The results are consistent with those of Borts (1960), who found that states with declining growth rates in manufacturing employment suffered larger fluctuations in employment over the business cycle.

In order to interpret changes in growth rates as measures of economic performance, this analysis uses time series data for gross state products (GSP) rather than state employment series. The latter have been used in most previous studies despite the lack of a definitive correspondence between employment changes and the vitality of a state's economy. For example, slowdowns or declines in employment growth may be due to productivity improvements, changes in an area's industry mix, recessions, or long-term structural adjustments.

The next section provides a brief review of previous work on the growthvolatility relation. Section III reports on the extent to which slower economic growth and deindustrialization in the manufacturing sector occurred in state economies during the $1976-86$ period. It is followed by the development and estimation of the regional volatility model mentioned above. A final section contains conclusions and implications for the extent to which policymakers are able to simultaneously achieve the goals of stronger growth and greater stability for their economies.

\section{THE GROWTH-VOLATILITY CONNECTION}

Recent reviews on the determinants of regional economic volatility have found that growth and industry mix variables have received most of the attention in previous work (Kozlowski 1987; Sherwood-Call 1990). While there is considerable debate over how industry mix effects should be measured, there is a consensus that a region's vulnerablity to slowdowns and strength in subsequent expansions are dependent upon its portfolio of industries. Areas with greater volatility have been shown to possess larger percentages of firms whose product 
demands are highly sensitive to changes in consumer income and therefore to the state of the macroeconomy.

There is less agreement on the relationship between economic growth and volatility. Early empirical work by Borts (1960) covered the 1914-53 period for manufacturing employment. It yielded some support for the position that faster growing states tend to experience larger cyclical fluctuations than states with slower growth. However, seemingly ignored in all subsequent analyses has been his second finding. During this period, there was a strong and consistently negative relationship between changes in the trend rate of state employment growth and employment cycle amplitudes, even when controlling for industry mix effects in measuring the cyclical swings. Borts concluded that declines in growth are likely indicative of a loss in competitive status caused by the onset of higher costs relative to other state economies. The importance of considering changes in growth rates is illustrated by the work of Cho and McDougall (1978). They hypothesized that faster growing areas should possess productive and locational cost advantages, which help to moderate downturns and facilitate steadier growth during expansions, but they failed to find any relation over the 1954-75 period between income growth rates and the cyclical volatility of metropolitan area employment. By way of explanation, Cho and McDougall emphasized the need to measure cyclical volatility properly. They speculate that the insignificant results for income may have been due to statistical limitations in the use of spectral measures of business cycle volatility.

Using quarterly total employment data at the state level for the 1955-84 period, Norrbin (1988) found no relation between peak-to-peak growth rates and cyclical employment variability. Again, the latter was adjusted for differences in industry mix. There was a negative relation for the 1955-69 subperiod. Kozlowski (1987) estimated a negative effect for the impact of average annual personal income growth upon cyclical employment volatility in U.S. metropolitan areas. Cyclical volatility was measured by the means of trend-adjusted cyclical amplitudes derived from monthly employment data for the 1954-83 period. A decomposition of cyclical movements into expansion and contraction components revealed that the strongest effect for faster growth was in reducing the severity of employment contractions during downtums. Kozlowski termed this the "growthbuffer effect," which is analogous to Borts' conjecture that growing areas have cost advantages that help to offset cyclical reductions in demand.

A similar effect for individual industries (textiles, paper, chemicals, and instruments) was found by Strong (1983). Across regions of the United States, he estimated a negative relation between the duration of an industry's employment contraction, due to the 1974-75 recession, and the industry's regional productivity relative to its national average productivity. This provided support for his mar- 
ginal supplier hypothesis, which suggested that regions with higher-cost industries experience longer employment downtums during recessions and weaker employment uptums during subsequent expansions. Also at the industry level, regional differences in the growth of market demand, as well as labor productivity differentials, tended to be significant determinants of trend-adjusted employment changes during both recession and expansion years.

In contrast to the faster growth-reduced volatility hypothesis tested in the above work, Sherwood-Call (1990) has extended the portfolio theory of regional economic performance previously used to examine the growth-volatility relation. Estimates derived from gross state product data confirmed the traditional result that states with more diversified portfolios of industries experience significantly less volatility, especially when considering the magnitude of fluctuations unrelated to the state of the national economy. However, for a more complete analogy with financial portfolio theory, Sherwood-Call maintained that the systematic sensitivity of state output growth to changes in national growth (measured by a regression coefficient similar to the beta parameter calculated for corporate stocks) should be positively related to a state's average rate of growth. The lack of any significant relation between average growth and systematic sensitivity underscored her critique of the portfolio model of regional economic analysis. Specifically, she argued that a trade-off between systematic stability and growth may not exist because: (1) a firm's (or industry's) performance may vary by location, whereas an individual stock's retum is invariant across investors; (2) not all states have the necessary resources to produce all products, whereas every investor can purchase every stock; and (3) there is no market for instantaneously trading firms or industries among states as there is for stocks among investors. Thus, within the portfolio model of regional economic activity, there may be no trade-off between stability and growth. As a result, when properly applied in a regional context, the portfolio model does not imply that volatility be positively related to growth.

The present analysis seeks to address the concerns raised about previous work. First, it compares the output and employment records of state economies for the 1963-86 time period and demonstrates that performance assessment is strongly dependent upon the measure of economic activity examined. Because output is an unambiguous indicator of the direction and magnitude of economic growth or decline, it is chosen as the variable to be assessed. With an emphasis on the effects of changes in long-term growth, this also enables a comparison of results for output with those of Borts for employment.

Second, in order to be more useful to policymakers and other economic decision makers, the analysis focuses upon the determinants of the total volatility of state output. Others have assessed either the responsiveness of state economic activity to the macroeconomy (Connaughton and Madsen 1987; Sherwood-Call 
1990) or the impact of state growth upon different measures of volatility such as those adjusted for industry mix (Norrbin 1988) or defined according to the average amplitude of a state's business cycles (Kozlowski 1987). While the aforementioned variables addressed useful research questions, total volatility, defined to be the standard deviation of annual growth rates as in Sherwood-Call (1990), is a summary measure of the observed fluctuations in annual output that a state's economy has experienced. It thus provides an estimate of the expected range in annual economic performance that decision makers can use for planning and forecasting purposes. Finally, in contrast to the use of various diversity indexes or portfolio measures in previous work, industry mix is measured by the shares of total output produced by cyclically sensitive industries such as durable manufacturing and mining. Again, the emphasis is upon using variables that can be measured and interpreted in a straightforward manner while avoiding the shortcomings associated with index and portfolio variables that are discussed below.

\section{THE SLOWDOWN IN OUTPUT GROWTH}

Table 1 reports for each state the average annual growth rates in GSP for total private sector output and manufacturing output over the 1963-73 and 197686 time periods. ${ }^{1}$ States are grouped according to their performance relative to the national economy for both periods. The 1974-75 recession is used to divide the 1963-86 time series into two subperiods since there is considerable evidence that a major slowdown in national productivity growth resulted from the structural dislocations that occurred during that recession (Crandall 1986). Cited as contributing factors by Lawrence (1984) were the stagflation initiated by the rapid rise in oil prices, the onset of an era of exchange rate volatility, the economic emergence of Japan and other newly industrialized countries, and increased amounts of intervention in intemational trade by govemments throughout the world. Deletion of the 1974-75 growth rates from both series enables a comparison of longer-term average growth rates without assigning the negative performance of the transition years to either period.

Focusing initially upon total GSP for the U.S. economy, the decline in average annual growth from 3.99 percent for 1963-73 to 3.28 percent for $1976-86$ represented a 18 percent reduction in the average rate of growth. In 10 of 48 states, the growth rate increased by an average of 1.17 percentage points, while it fell by 1.19 points in the remaining 38 states. Increases in growth rates occurred in New England and the western region of the country. States that grew faster than the national average in both time periods (Group I) and those that moved 
TABLE 1

Annual Averages For GSP Growth

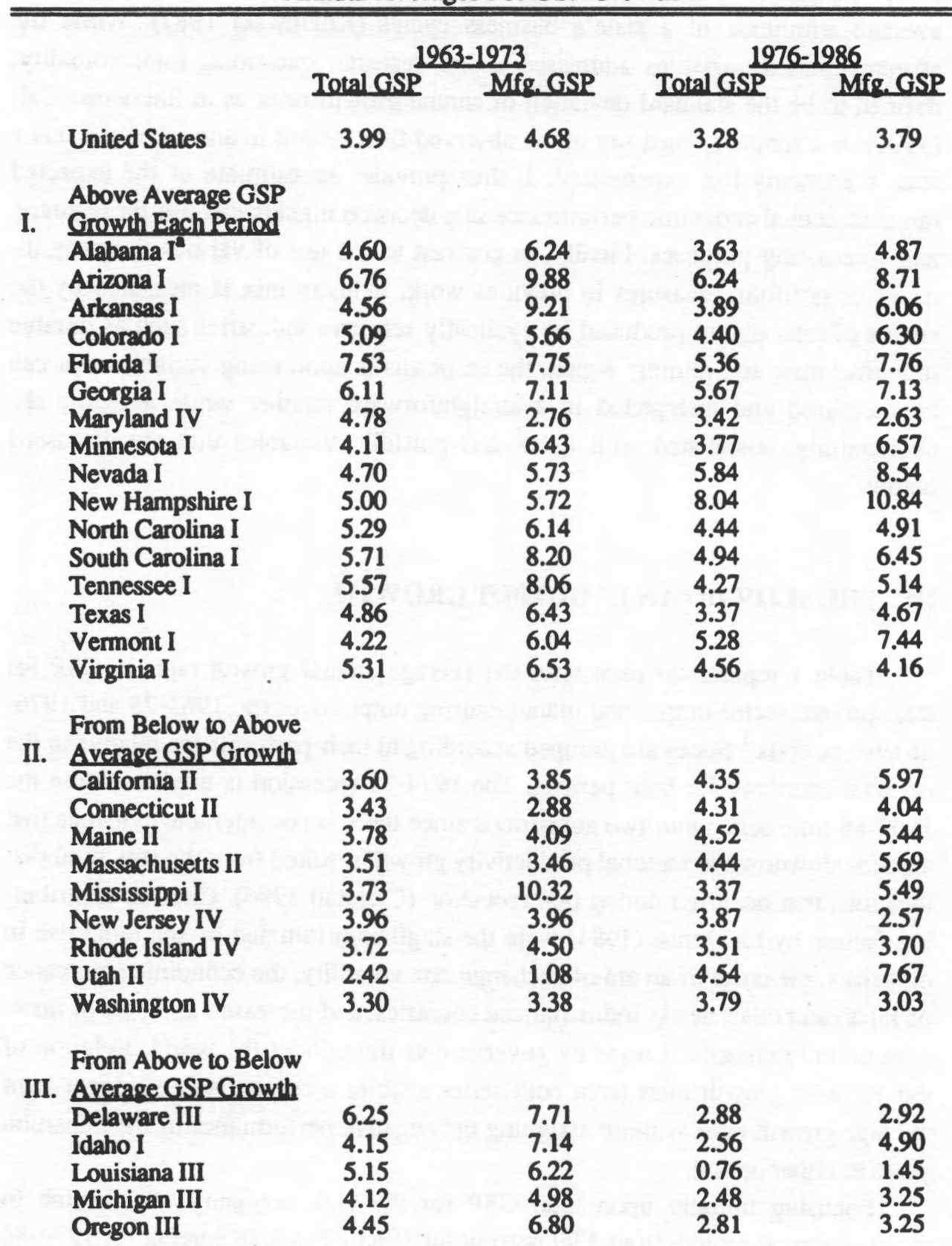


TABLE 1 (Continued)

\begin{tabular}{|c|c|c|c|c|}
\hline & \multicolumn{2}{|c|}{$1963-1973$} & \multicolumn{2}{|c|}{$1976-1986$} \\
\hline & Total GSP & Mfg, GSP & Total GSP & Mfo, GSP \\
\hline \multicolumn{5}{|c|}{$\begin{array}{l}\text { Below Average GSP } \\
\text { IV Growth Each Period }\end{array}$} \\
\hline Illinois IV & 3.29 & 4.44 & 1.66 & 1.13 \\
\hline Indiana III & 3.66 & 4.72 & 2.16 & 2.25 \\
\hline Iowa III & 3.34 & 6.44 & 1.77 & 3.41 \\
\hline Kansas I & 2.78 & 5.90 & 2.42 & 3.83 \\
\hline Kentucky III & 3.89 & 5.80 & 2.62 & 2.07 \\
\hline Missouri I & 3.57 & 5.25 & 3.06 & 4.22 \\
\hline Montana IV & 3.23 & 4.62 & 1.63 & -0.75 \\
\hline Nebraska I & 3.39 & 6.95 & 2.53 & 4.37 \\
\hline New Mexico I & 2.47 & 6.15 & 3.00 & 8.64 \\
\hline New York IV & 2.91 & 2.44 & 2.53 & 4.37 \\
\hline North Dakota III & 3.84 & 13.34 & 1.92 & 2.97 \\
\hline Ohio IV & 3.62 & 4.55 & 2.13 & 2.36 \\
\hline Oklahoma I & 3.76 & 7.15 & 2.30 & 4.98 \\
\hline Pennsylvania IV & 3.32 & 3.59 & 1.76 & 0.76 \\
\hline South Dakota I & 3.12 & 6.68 & 2.21 & 7.77 \\
\hline West Virginia IV & 2.81 & 2.08 & 1.18 & -0.92 \\
\hline Wisconsin I & 3.68 & 5.04 & 3.20 & 4.10 \\
\hline Wyoming IV & 2.36 & 2.90 & 1.88 & -2.58 \\
\hline
\end{tabular}

Roman numeral after state name indicates group membership for change in manufacturing GSP growth rate.

Source: U.S. Bureau of Economic Analysis, Gross State Product tape, 1988.

from below to above average growth (Group II) were primarily southern, western, and New England states. The five states that moved from above to below average growth (Group III) all experienced majors declines in annual growth, with Louisiana falling below 1 percent during 1976-86. The states in Group IV are mainly those in the central regions of the country along with New York and Pennsylvania. While attention has focused upon the decline of states in Group IV since the mid-1970s, it is apparent that in comparison with the rest of the nation the decline has been underway since the $1960 \mathrm{~s}^{2}$

Deindustrialization was the term advanced by Bluestone and Harrison (1982) to describe an apparent structural decline in U.S. manufacturing activity, which culminated in the severe recession of 1982 . The long-term nature of the process was emphasized by attempting to demonstrate a systematic underallocation of resources to new productive capacity in the domestic manufacturing sector. Controlling for business cycle and exchange rate effects, they also documented significant negative shifts in the employment growth rates of many manufacturing industries during the 1970s and early 1980s (Bluestone et al. 1986). 
Lawrence (1984) stressed the difficult nature of the economic adjustment problems implied by deindustrialization and therefore looked for absolute declines in the use of productive inputs in manufacturing to identify such a process. For 1973-80, he found no evidence of widespread deindustrialization for the U.S. economy, with most employment declines due to productivity improvements, slower GNP growth, and unfavorable exchange rate movements. For the automobile and steel industries, the most significant factor was weak domestic demand for their products. Using measures such as shares of total output and output growth, Connaughton and Madsen (1990) and Crandall (1986) reached similar conclusions for most of the United States except for states in the Great Lakes and Mideast sections of the country.

For state and local economies, Hill and Negrey (1987) defined deindustrialization as an extended period of manufacturing job losses that results in a declining share of national manufacturing employment. At the same time, there is a failure to generate offsetting job growth in other sectors. As in the case of the output studies cited above, they found evidence of deindustrialization for states and larger cities in the Great Lakes region of the United States.

Table 1 also shows the extent of manufacturing decline at the state level as measured by changes in average output growth over the two subperiods defined above. For the entire U.S. economy, there was nearly a one percentage point decline from 4.68 percent during $1963-73$ to 3.79 percent during $1976-86$, but in most states the growth rate in manufacturing output exceeded that of total output during both periods. The regional pattem for above versus below average manufacturing growth during the two periods is similar to that for total output growth, with group membership being the same for 31 of 48 states and most of the below average states being located in the central and eastem regions of the country. Average growth in manufacturing output was negative in only three states during 1976-86: Montana, West Virginia, and Wyoming. In absolute terms, the manufacturing sector grew in the remaining states and increased faster than total output in most cases. Only in relative terms, and only for 32 of 48 states, has there been deindustrialization in the sense of slower growth in output during the later time period.

Despite having below average manufacturing growth during both periods, there is evidence that some states have been successful in making the transition from reliance upon manufacturing by maintaining an above average rate of overall growth since 1976. Included in this group are Maryland, New Jersey, Rhode Island, and Washington. On the other hand, many of the more agriculturally oriented states of the Plains region experienced above average growth in manufacturing output during the entire 1963-86 period, while their total economic growth was slower in the second period (Idaho) or in both periods (Kansas, Mis- 
souri, Nebraska, New Mexico, Oklahoma, South Dakota, and Wisconsin). Connaughton and Madsen (1990) provide a more detailed analysis of changes in output for a broad spectrum of industries at the regional level.

Finally, there are important differences in the conclusions reached conceming the slowdown in economic growth and deindustrialization when comparing results based upon employment rather than output data. The upper portion of Table 2 shows the decade-long growth in private output and employment for the aggregate U.S. economy and the manufacturing sector for 1963-73 and 1976-86. During each decade, total output grew appreciably faster than total employment. However, the decline in output's growth rate exceeded employment's decline by 8.0 percentage points. For the manufacturing sector, superior labor productivity improvements resulted in very large differentials between output and employment growth in each decade. Whereas a 35.2 percent increase in manufacturing output during 1976-86 exceeded that for total output and represented substantial growth,

TABLE 2

A. Comparison of Output and Employment Records

(Percentage Increases)

\begin{tabular}{lcccc} 
& \multicolumn{2}{c}{$1963-1973$} & \multicolumn{2}{c}{$1976-1986$} \\
Total economy & Output & Employment & Output & Employment \\
Manufacturing & 47.5 & 33.0 & 34.9 & 28.4 \\
& 56.3 & 18.6 & 35.2 & -0.2
\end{tabular}

B. States with Manufacturing Employment Declines

(1976-1986)

\begin{tabular}{|c|c|c|c|}
\hline State & Decade \% Decline & State & Decade $\%$ Decline \\
\hline$\overline{\text { Connecticut }}$ & 0.5 & Nebraska & 2.2 \\
\hline Illinois & 23.8 & New Jersey & 8.7 \\
\hline Indiana & 11.8 & New York & 13.0 \\
\hline lowa & 13.8 & North Dakota & 5.6 \\
\hline Kentucky & 7.1 & Ohio & 14.3 \\
\hline Louisiana & 15.0 & Pennsylvania & 21.4 \\
\hline Maryland & 9.6 & Rhode Island & 3.3 \\
\hline Michigan & 5.8 & South Carolina & 1.6 \\
\hline Missouri & 0.1 & West Virginia & 30.2 \\
\hline Montana & 11.0 & Wisconsin & 0.9 \\
\hline & & Wyoming & 6.0 \\
\hline
\end{tabular}

Sources: 1. National output: see Table 1.

2. National employment: U.S. Bureau of Labor Statistics, Employment and Earnings, August 1992. Washington, D.C.: U.S. Government Printing Office, 1992.

3. State manufacturing employment: U.S. Bureau of Labor Statistics, Employment, Hours and Earnings, States and Areas, 1972-87. Washington, D.C.: U.S. Government Printing Office, 1989. 
an assessment based upon the 0.2 percent decline in manufacturing employment over the same period would indicate a stagnant industrial sector. In fact, the lower portion of Table 2 shows that 21 states suffered employment declines in manufacturing during 1976-86, ranging from less than 1 percent in Connecticut, Missouri, and Wisconsin to 30.2 percent in West Virginia, and averaging 9.8 percent over all these states. Thus, the analysis based upon output dynamics in the next section uses a variable more closely related to actual economic performance and offers a different view of the growth-volatility relation from that provided in most previous studies.

\section{AN ECLECTIC MODEL OF STATE OUTPUT VOLATILITY}

Attempts to empirically test hypotheses on the growth-volatility relation have assumed that a region's volatility is an endogenous outcome determined by forces that affect a region's growth and development processes. Consistent with this approach and for ease of interpretation as discussed above, the dependent variable in the cross-section regression model estimated below is total state output volatility (OUTVOL) measured as the standard deviation of annual GSP growth rates for the 1963-86 period. During this time, total GSP volatility across the 48 states averaged 3.74 percent, ranging from 2.31 for Kansas to 6.50 for Michigan. In the manufacturing sector, volatility averaged 6.66 percent and ranged from 4.47 in New York to 11.85 in Michigan. For both total output and manufacturing output, these values indicate a substantial amount of year-to-year fluctuation in economic performance at the state level. As a result, budget preparation by government officials and the production plans of local nonbasic sectors are subject to considerable uncertainty regarding future state output growth.

An important component of the neoclassical model of regional growth is that factors of production move to areas in which their rates of retum are increasing relative to those in other areas. Therefore, changes in long-term growth, not the long-term average, more closely reflect changes in the competitive positions of the different states. Because competitive advantages work at the margin for new investment and employment location decisions, a state with improving retums should experience less severe downtums during recessions and steadier growth during expansions. Thus, $\triangle$ GROWTH, the 1976-86 average annual state output growth rate minus the same rate for $1963-73$, is expected to have a negative impact upon OUTVOL. $\triangle$ GROWTH averaged -0.70 percentage points across the sample and ranged from -4.39 for Louisiana to 3.05 for New Hampshire. ${ }^{3}$

The dependence of a region's well-being upon extemal sources of demand is the main characteristic of Keynesian or export base models of economic growth. 
A region's mix of industries determines its fortunes according to the performances of its industries at the national level. Industry mix has often been measured by indexes that aggregate deviations either from national average industry shares or from a rectangular distribution of industry shares. Grossberg (1982) and Jackson (1984) found little empirical support for the power of such indexes to predict regional employment volatility. In general, indexes rely upon subjective definitions of a normal or desirable industry mix and fail to distinguish among the different growth and volatility impacts of different industries, especially with respect to multiplier and income elasticity effects. Portfolio variance measures of industry mix have also been called into question. Regional portfolio variances are often computed by applying regional weights (e.g., industry employment shares) to the variances of industry returns at the national level. By ignoring regional differences in industry retums, Grossberg argued that these variances are not precise measures of the relative riskiness of a region's portfolio of industries and may be unrelated to the volatility of a region's economy. Furthermore, Sherwood-Call (1990) demonstrated that portfolio variance measures do not define industrial diversity independent of total volatility measures of regional instability. As a result, there is a definitional dependence between volatility and diversity prior to the estimation of any behavioral relation.

In contrast, simpler industry share variables have proven effective in previous empirical work. For metropolitan employment, greater vulnerability to recession has been associated with larger shares of manufacturing employment (Victor and Vernez 1981) and durable manufacturing employment (Kozlowski 1987). Less severe volatility has been observed in states with larger employment shares in the nondurable goods and financial sectors of the economy (Norrbin 1988). Thus, two sectors highly sensitive to national and intemational economic conditions are used to construct industry share measures of mix. The average percentages of private output in durable manufacturing (DURABLE SHARE) and mining (MINING SHARE) should be positively related to OUTVOL at the state level. The former industry is dependent upon macroeconomic forces, particularly changes in national income and employment. The latter is subject to intemational fluctuations in commodity markets, with the volatility of energy prices having a strong impact upon annual changes in output shares. The influence of longer-term adjustments in industrial structure is captured by $\triangle$ SERVICES SHARE, the change from 1963 to 1986 in the share of total private output produced by the services industries. Increases in this variable are expected to reduce the magnitude of an area's response to the business cycle and therefore result in lower values of OUTVOL.

Cumulative causation models of regional growth stress the agglomeration and infrastructure benefits of larger and more mature areas of economic activity. 
Such places are expected to experience less volatility due to their productive advantages and the more secure financial status of larger industries and their member firms. Brewer and Moomaw (1985) found greater total employment and manufacturing employment stability in larger metropolitan areas, and Howland (1984) estimated a negative relation between employment declines during recessions and the age of a state's capital stock. RGSP63 measures real gross state product in 1963 (in billions of 1982 dollars), and since larger economies are hypothesized to be more stable, a negative relation between RGSP63 and OUTVOL is anticipated. Last, other regional cost or demand factors not accounted for by the variables described above are included in three dummy variables defined according to the major census regions: NORTH CENTRAL, SOUTH, and WEST.

Results for an ordinary least squares regression model estimated to identify the determinants of GSP volatility are shown in the upper portion of Table 3. Each of the non-dummy coefficients has the anticipated sign and is significant at the 0.05 level for a one-tail test, with the exception of the parameter for MINING SHARE, which is significant at the 0.10 level. Although none of the region dum-

TABLE 3

Regression Results

Model 1: Total Volatility of GSP

\begin{tabular}{|c|c|c|c|}
\hline Variable & Coefficient & Standard Error & $\begin{array}{l}\text { Coefficient } x \\
\text { Standard Deviation }\end{array}$ \\
\hline INIERCEPT & 3.776 & 0.517 & $-\infty$ \\
\hline$\triangle$ GROWTH $(-0.70)$ & -0.391 & 0.124 & -0.500 \\
\hline DURABLE SHARE (13.34) & 0.039 & 0.022 & 0.266 \\
\hline MINING SHARE (6.31) & 0.017 & 0.013 & 0.188 \\
\hline $\triangle$ SERVICES SHARE (3.06) & -0.218 & 0.092 & -0.323 \\
\hline RGSP63 (33.33) & -0.006 & 0.003 & -0.238 \\
\hline NORTH CENTRAL (0.25) & 0.181 & 0.403 &.- \\
\hline SOUTH $(0.33)$ & -0.682 & 0.434 & $-\cdots$ \\
\hline WEST (0.23) & 0.479 & 0.402 & -- \\
\hline
\end{tabular}

Model 2: Total Volatility of Manufacturing GSP

\begin{tabular}{|c|c|c|c|}
\hline INTERCEPT & 4.532 & 1.108 & - \\
\hline $\begin{array}{l}\triangle M F G \text { GROWTH }(-1.32) \\
\text { DURABLE SHARE-MFG (56.98) }\end{array}$ & $\begin{array}{r}-0.140 \\
0.031\end{array}$ & $\begin{array}{l}0.077 \\
0.017\end{array}$ & $\begin{array}{r}-0.403 \\
0.428\end{array}$ \\
\hline MFG RGSP63 (8.26) & -0.036 & 0.019 & -0.383 \\
\hline NORTH CENTRAL $(0.25)$ & 1.102 & 0.617 & -- \\
\hline SOUTH $(0.33)$ & 0.150 & 0.618 & -.. \\
\hline $\begin{array}{l}\text { WEST }(0.23) \\
\mathbf{R}^{2}=.30\end{array}$ & 0.563 & 0.609 & -- \\
\hline
\end{tabular}

Variable means in parentheses. 
mies is significant at the $\mathbf{0 . 1 0}$ level for a two-tail test, there is some indication of less output volatility in Southem states, especially when compared to those located in the West. In order to compare the relative importance of each factor, the final column presents the coefficient multiplied by the standard deviation for each continuous variable in the model.

Of those considered, the strongest factor working to reduce annual output volatility is an increase in a state's long-term growth rate. The difference in impact between one positive and one negative standard deviation from the average change in growth is a full percentage point in a state's volatility, or more than 25 percent of the average state's output volatility. Thus, there is strong evidence in favor of the stabilizing effects of improved growth and the increased volatility accompanying slowdowns in growth. There is no trade-off between increased growth and stability in the aggregate performance of state economies.

Next in importance for achieving less volatility is faster transition to a service-oriented economy. A standard deviation increase in the change in services' output share, amounting to 1.48 percentage points, results in a nearly one-third percentage point reduction in volatility. The greater cyclical sensitivity of the durable goods manufacturing and mining industries is reflected in the significant increases in volatility associated with greater average shares of output in those sectors. Thus, while growth itself is not a volatility-inducing process, greater concentrations of activity in these export base sectors would lead to a less stable state economy. Finally, states with larger economies at the start of the time series tended to experience less volatility, a result consistent with previous findings of smaller fluctuations in larger and more established economies.

Given the research attention focused upon the adjustment difficulties faced by workers in regions experiencing deindustrialization in terms of manufacturing employment declines, a similar model was estimated for manufacturing output volatility. The lower portion of Table 3 shows that the average slowdown in manufacturing growth ( $\triangle$ MFG GROWTH) was nearly double that for total output. It ranged from -10.38 percentage points for North Dakota to 6.60 for Utah. The results for manufacturing are generally consistent with those for total output. States that managed to generate an increase in growth had less volatility, while larger declines in growth were associated with greater volatility. States that began with larger manufacturing sectors (MFG RGSP63) were more stable, but those with a greater average share of manufacturing output originating in the durable goods sector (DURABLE SHARE-MFG) tended to suffer from increased volatility. States in the North Central region appear to have had less stable manufacturing sectors when compared to states in the Northeast and South. 


\section{SUMMARY}

The empirical evidence presented above provides little or no support for the notion that widespread deindustrialization occurred during the 1970s and early 1980s. Although total output and manufacturing output growth slowed to some extent, the average decline was not severe, and manufacturing growth continued to exceed that for total output. However, there was considerable variation across states in the amount by which growth slowed, with the geographical distribution of slower manufacturing output growth being similar to that for manufacturing employment declines. States in the North Central region and non-New England states in the Northeast tended to experience slower than average growth during both periods of analysis.

Results from regression models specified to determine the factors associated with economic volatility are consistent with the models of regional growth and development identified above. The chief finding is that state output volatility is related to changes in long-term growth and not to the absolute level of growth. The significant negative relation most closely resembles Borts' finding of more severe employment fluctuations in slower growing states during business cycles in the first half of the 1900s. It also supports Kozlowski's conclusion that employment downturns during recessions are buffered in areas with more rapid growth. The existence of a growth-stability trade-off, implied in portfolio models of regional economic performance, is not consistent with the estimation results. Thus, it appears that states can achieve both faster growth and greater stability when they are viewed as competitive locations for business activity. To the extent that growth occurs in the services sector, the stability effect is even stronger.

There also seems to be a stabilizing influence related to absolute size, as states with larger economies tend to have smaller fluctuations in subsequent years. However, one caveat to these conclusions is the result that increased concentrations of activity in export-oriented sectors subject a state's economy to greater volatility. Greater relative growth in durable goods manufacturing and mining activity contributes to larger annual fluctuations. Thus, in this case, a trade-off between increased growth and stability may exist.

\section{ENDNOTES}

1. The analysis is conducted for the $\mathbf{4 8}$ contiguous states. Alaska is omitted due to the dominance of its economy by the mining sector after construction of the oil pipeline. Inconsistencies in the coverage of the time series for some of the major sectors of the Hawaiian economy resulted in its omission as well. GSP data 
recently became available for $1987-89$ as part of an update and revision of the 1977-86 time series. However, due to changes in the methodology of calculating GSP estimates by industry, the newer data was not merged with the original 196386 data set. See Trott et al. (1991) for a comparison of the two GSP time series.

2. These differentials in economic performance between the Sun Belt and Snow Belt regions during this period have also generated considerable study. Among those taking a longer-term approach to identifying explanations for this differential, Yu et al. (1991), Barro and Sala-I-Martin (1991), and Hulten and Schwab (1984) have concluded that differences in factor growth rates consistent with theories of regional convergence are largely responsible. Other forces that have been identified include regional differences in taxes (Helms 1985; Plaut and Pluta 1983; Wasylenko and McGuire 1985), the impact of technological changes and factor price differentials upon production, communication and transportation costs (Chinitz 1986; Booth 1986; Greenwood 1988), and spatial shifts in population and income growth, which have changed the relative positions of demand and supply in output markets of the various regions (Wheat 1986).

3. OUTVOL includes both positive and negative fluctuations in output. It is not the case that it is only capturing the differences across states in vulnerablity to downturns. If that were so, higher values of OUTVOL would be associated with lower long-term growth. Use of 1963-86 average growth rates in place of $\triangle$ GROWTH resulted in insignificant effects upon OUTVOL for both the total output analysis and the analysis limited to manufacturing output discussed below. This is consistent with the theoretical model and is expected given the significant changes in state output growth rates after the 1974-75 recession.

\section{REFERENCES}

Barro, Robert J., and Xavier Sala-I-Martin. "Convergence Across States and Regions." Brookings Papers on Economic Activity no. 1 (1991): 107-158.

Bluestone, Barry, and Bennett Harrison. The Deindustrialization of America. New York: Basic Books, 1982.

Bluestone, Barry, Bennett Harrison, and Alan Clayton Mathews. "Structure vs. Cycle in U.S. Manufacturing Job Growth." Industrial Relations 25 (1986): 101-117.

Booth, Douglas E. "Long Waves and Uneven Regional Growth." Southern Economic Journal 53 (1986): 448-460.

Borts, George H. "Regional Cycles of Manufacturing Employment in the United States, 1914-1953." Journal of the American Statistical Association 55 (1960): 151-211. 
Brewer, H. L., and Ronald L. Moomaw. "A Note on Population Size, Industrial Diversification, and Regional Economic Instability." Urban Studies 22 (1985): 349-354.

Chinitz, Benjamin. "The Regional Transformation of the American Economy." Urban Studies 23 (1986): 377-385.

Cho, Dong W., and Gerald S. McDougall. "Regional Cyclical Pattems and Structure 1954-1975." Economic Geography 54 (1978): 66-74.

Connaughton, John E., and Ronald A. Madsen. "Measuring Cyclical Sensitivity in State Performance: 1969-84." Regional Science Perspectives 17 (1987): 3440.

. "The Changing Regional Structure of the U.S. Economy." Growth and Change 21 (1990): 48-60.

Crandall, Robert W. "The Transformation of U.S. Manufacturing." Industrial Relations 25 (1986): 118-130.

Greenwood, Michael J. "Changing Patterns of Migration and Regional Economic Growth in the U.S.: A Demographic Perspective." Growth and Change 19 (1988): 68-87.

Grossberg, Adam J. "Metropolitan Industrial Mix and Cyclical Employment Stability." Regional Science Perspectives 12 (1982): 13-35.

Helms, L. Jay. "The Effect of State and Local Taxes on Economic Growth: A Time Series-Cross Section Approach." Review of Economics and Statistics 67 (1985): 574-582.

Hill, Richard Child, and Cynthia Negrey. "Deindustrialization in the Great Lakes." Urban Affairs Quarterly 22 (1987): 580-597.

Howland, Marie. "Age of Capital and Regional Business Cycles." Growth and Change 15 (1984): 29-37.

Hulten, Charles R., and Robert M. Schwab. "Regional Productivity Growth in U.S. Manufacturing: 1951-78." American Economic Review 74 (1984): 156162.

Jackson, Randall W. "An Evaluation of Altemative Measures of Regional Industrial Diversification." Regional Studies 18 (1984): 103-112.

Kozlowski, Paul J. "Regional Cyclical Volatility: Tests of a Growth-Buffer Hypothesis." Regional Science Perspectives 17 (1987): 41-56.

Lawrence, Robert Z. Can America Compete. Washington, D.C.: Brookings Institution, 1984.

Norrbin, Stefan C. "Determinants of Differences in Regional Cyclical Variability." Review of Regional Studies 18 (1988): 16-22.

Plaut, Thomas R., and Joseph E. Pluta. "Business Climate, Taxes and Expenditures, and State Industrial Growth in the U.S." Southern Economic Journal 50 (1983): 99-119. 
Sherwood-Call, Carolyn. "Assessing Regional Economic Stability: A Portfolio Approach." Federal Reserve Bank of San Francisco Economic Review (Winter 1990): 17-26.

Strong, John S. "Regional Variations in Industrial Performance." Regional Studies 17 (1983): 429-444.

Trott, Edward A., Ann E. Dunbar, and Howard L. Friedenberg. "Gross State Product by Industry, 1977-89." Survey of Current Business 71 (December 1991): 43-59.

Victor, Richard B., and George Vemez. Employment Cycles in Local Labor Markets. Santa Monica, Calif.: Rand Corporation, 1981.

Wasylenko, Michael, and Therese McGuire. "Jobs and Taxes: The Effect of Business Climate on States' Employment Growth Rates." National Tax Journal 38 (1985): 497-511.

Wheat, Leonard F. "The Determinants of 1963-77 Regional Manufacturing Growth: Why the South and West Grew." Journal of Regional Science 26 (1986): 635-659.

Yu, Wei, Miles S. Wallace, and Clark Nardinelli. "State Growth Rates: Taxes, Spending, and Catching Up." Public Finance Quarterly 19 (1991): 80-93. 